\title{
ANTHROPOCENTRIC MODEL OF DISCOURSE
}

\author{
CUsmonova D., ORCID: 0000-0002-6273-5593, \\ Alisher Navoi Tashkent State University of Uzbek Language and Literature, \\ Tashkent, Uzbekistan,dilnozausmanova@gmail.com
}

\section{АНТРОПОЦЕНТРИЧЕСКАЯ МОДЕЛЬ ДИСКУРСА}

\author{
СУсмонова Д. У., ORCID: 0000-0002-6273-5593, \\ Ташкентский государственный университет узбекского языка и литературы им. А. Навои, \\ 2. Ташкент, Узбекистан, dilnozausmanova@gmail.com
}

Abstract. The article delves into the new approaches to discourse highlighting its communicative, cognitive, pragmatic and linguocultural aspects. The aim is to scrutinize the notion of discourse in relation with human factor in different communicative settings. It is acknowledged that studies on the current topic area can be more successful by the integration of anthropocentric paradigm.

Аннотация. В статье рассматриваются новые подходы к дискурсу, подчеркивающие его коммуникативный, когнитивный, прагматический и лингвокультурологические аспекты. Цель состоит в том, чтобы изучить понятие дискурса в отношении человеческого фактора в различных коммуникативных условиях. Признано, что исследования в данной тематической области могут быть более успешными при условии интеграции антропоцентрической парадигмы.

Keywords: discourse, communicative theory, pragmatics, anthropocentric paradigm, cognitive linguistics, linguoculturology.

Ключевые слова: дискурс, коммуникативная теория, прагматика, антропоцентрическая парадигма, когнитивная лингвистика, лингвокультурология.

Language as a means of realization of certain communicative aim becomes an object in linguistic studies. The communicative aim in the linguistic material may not always be clear as it should be interpreted within certain cognitive frames. Modern tendency in linguistic science to explain the general patterns and mechanisms of human interpretation and activization of specific linguistic information has emerged a great interest in discourse studies. The term 'discourse' came into existence from Latin language meaning movement, succession and being interdisciplinary notion has a close relationship with the term 'text'. Several researchers have attempted to define the correlation between text and discourse. (I. R. Galperin, V. I. Karasik, T. A. van Dijk, E. S. Kubryakova) According to Ashurova D. U. text and discourse are interrelated but they are not equivalent [1, p. 76]. Although there is no standard definition of the 'text' in science, all scientists agree that a text is a product of the language which has an intricate structure and its own content. Halliday states that, text can be anything which has a meaning in certain situation. In this approach to the text cohesive connection between the elements in connected sentences of the text, for 
instance, in what ways one word or phrase is linked to other word or phrases is put in the foreground of the investigation. Halliday considers the text as a realization of discourse and discourse as an abstract concept [2, p. 142]. Similarly, studies such as that conducted by Brown and Yule have shown that one of the notions, text and discourse can be considered as a product of the communicative act while the other one can refer to the abstraction, - the activities surrounding the product [3, p. 24]. Preceding the previous research Crystal highlighted that a number of linguists have agreed to consider the text as a physical product and discourse as a dynamic process of linguistic expression and interpretation [4, p. 148]. As our material has shown, text is sometimes equated with a written form of speech, while discourse is related to the oral form of communication. The oral communication as well as the written communication, always occurs in a certain context and communicative situation. This situation in its turn integrates other extra linguistic factors such as, cultural, social, economic-political, historical, religious knowledge into the process of interaction. The need for deep study the means of language units as a linguistic phenomenon and its correlation with the sense which appears in a communicative situation as a result of interaction between linguistic and extra linguistic factors raised the importance of discourse studies. A number of researchers have reported on the problem of discourse. Many scientists introduced various points of view, assumptions and approaches to investigate the problem (N. D. Arutyunova, E. Bennevist, A. A. Kibrik, T. A. van Djik, M. Stabs, E. S. Kubryakova, V. I. Karasik). The term discourse analysis was first introduced by Zellig Harris in 1952 [4, p. 30]. He argues that random collections of sentences do not have a clear structure above the sentence level, while the text would have the form as a larger whole. Of course, it should be kept in mind that a text is usually characterized with its cohesion and any set of sentences may not have this feature even if they bear certain communicative meaning. In the same vein, Widdowson associates the textual analysis with cohesion, and the discourse analysis with the properties of cohesion and coherence [6, p. 34]. In modern linguistics discourse analysis is ambigiuos notion. M. Stubbs suggests three main characteristics of discourse [7, p. 1]:

$-\mathrm{a}$ discourse is a unit above the sentence;

-according to semantic content discourse e analysis aims on the socio-cultural context;

-interactive dialogic structure is the most important character of the discourse.

V. Karasik defines discourse as a text in the situation of real communication. He suggests analyzing discourse from linguistic, sociolinguistic and pragmatic perspectives [8, p. 15]. From linguistic point of view, discourse is characterized by its completeness, correctness and logicality. The sociolinguistic approach focuses on the participants of the discourse, their linguistic knowledge and social background. The linguopragmatics deals with the mode of discourse - the channel of interaction, register, style and genre of communication. This finding corroborates the assumptions of N. D. Arutyunova who describes the discourse as a connected text in combination with extra linguistic factors such as, pragmatic, sociocultural and psychological and etc. factors: text, taken in eventual aspect, is speech being analyzed as a purposeful social action, which takes part in interaction between people and serves as a mechanism of their cognition [9, p. 137]. However, she claims that the term discourse cannot be applied to ancient texts as the connection between them is impossible to restore.

In modern linguistics of great interest is the anthropocentric paradigm which puts the human factor in the center of linguistic analysis of the social activity. In accordance with the anthropocentric hypothesis the study addresses several further questions on communicative linguistics, linguopragmatics, cognitive linguistics, linguoculturology and ethnolinguistics.

The controversy over the communicative theory of text has raged for many years and several theories have been proposed to explain the text and its communicative character (I. R. Galperin, 
G. V. Kolshanskiy, O. G. Moskalskaya, E. S. Kubryakova). The first attempts to define the communicative nature of the text can be found in the works of M. M. Bakhtin. He regarded the text as an element of the communication and in the outside of the interaction it cannot be understood fully. M. M. Bakhtin's findings might have been more persuasive if he had considered the main parameters of the communication process [10, p. 255]. In accordance with the previous studies, G. V. Kolshanskiy demonstrated that the text is a main unit of communication and the text in this process can reveal the full, concrete communicative act, whereas, the communication itself displays complete informative act [11, p. 176]. Obviously, in this process the main parameters of the communication are reflected in the text: speaker (subject of the speech, text producer or sender, addresser) - listener (recipient, addressee) - referent (world fragment, objects, images). Kubryakova suggests that the text is informative, all-sufficient speech message which has a concrete purpose and according to its meaning oriented to the addressee [12, p. 18]. Furthermore, she considers that even sentences or utterances (having implications of a predicate but not explicitly containing it) which are taken as a separate entity in some circumstances can be considered to be all-sufficient. For instance, this type of texts can be headings or the titles of literary works as they might be understandable for the reader under certain circumstances even if they do not have all peculiarities of normal text form. The communication realized with the help of the text between addresser and addressee has been further investigated by other scholars [13-14] as a system of actions or activity which is intended on the one hand, on the text production, on the other - on text perception (understanding, interpretation of the text). The evidence presented in these studies suggests that text should be acknowledged as a communicative unit with dual character and it should be perused from both addresser's and addressee's points of view.

The problem of text analysis from the communicative perspective requires the investigation of linguistic and extra-linguistic factors of communication. The linguistic factors include the choice and arrangement of language units relating to all levels of language hierarchy regarding the language and speech characteristics, grammatical paradigms, semantic and syntactical relations in the text. In the same way, extra-linguistic factors contain the personality of the addresser and addressee, aims and tasks of the communication, sociocultural conditions of the communication. In this respect, the role of presuppositions, background knowledge, and cultural context should be especially of great importance.

So, communicative approach to discourse suggests:

-Text should be considered as a dynamic model of reciprocal communicative act.

-Definition of the text immersed in a real communicative situation in accordance with sociocultural context.

-Text should be investigated concerning both the process of text production and text perception in relation with the factors of addresser and addressee.

-Text analysis should be conducted considering the relationship between the participants of the communicative act in regard with communicative postulates and principles

To determine the mechanisms of text creation it is important to know pragmatic setting of the text and the author. Text as a complete speech production follows certain rules of text building. Text formation occurs under the influence of intentionality of the text itself and intentionality of the author. The first is embedded in the text itself, its type, genre, the tasks it accomplishes. The second is entirely related to the author's modality, since any message contains not only information, but also the author's attitude to the information being reported. The latter is especially important in establishing the pragmatics of the text, since it is connected with the interpretational aspect of the text. The author not only forms the actual text, but also guides the reader in his interpretation of the text. Even in the usage of the little fragment of the text - indentation we can 
distinguish between two types of intentionality: textual intentionality and author's intentionality. For instance, indentation being semantically, and structurally complete unit is basically used to merge different ideas into one coherent text. However, on the behalf of the author indentation can break the unity of the text pursuing the goals of an emotional, aesthetic plan, or, conversely, combine several linguistic units into one big paragraph.

The study of the text as a means of social interaction examines language functioning within the human activity which encompasses psychological, social and cultural language peculiarities. Linguopragmatics emerged as a result of ideas relating to functions and use of language by scientists such as Austin, Searle and Grice. According to our investigation, linguopragmatics deals with a wide range of problems, but not all of them are relevant to the text linguistics. Following pragmatic problems are in the focus of text linguistics:

-speech strategies and speech impact;

-pragmatic intentions and their types;

-appropriateness and effectiveness of textual communication.

As the human factor is considered to be one of the principal factors in analyzing the text, pragmatics studies all conditions in which human applies language signs for communication. In this regard, selection and use of appropriate language units for the communicative situation is considered as the conditions of the communication. An important pragmatic character is the position of the addresser in relation to the addressee - socio-conditional status of the communicants.

Pragmatics is also concerned with the functions of utterances such as, informing, requesting and promising, which uttered by a speaker - a performer of a speech act. This theory was introduced in the pioneer work of J. L. Austin and further developed by J. Searle and H. P. Grice. Austin puts the accent on the pragmatic phenomena which appear in speech, that is to say, the discourse may accomplish an action [15, p. 167]. According to the speech act theory, the meaning of the utterances is divided into three speech act types: 1) what is uttered - locution; 2) the performative meaning that can be interpreted - illocution; 3) the effect or result of the speech - perlocution. Among this speech acts illocutionary act is considered to be the central moment. Austin's work on pragmatics is further complemented by G. Grice's investigations on pragmatic principles of building effective communication. G. Grice offers to consider the principle of cooperation as a predominant principle of communication and any kind of speech act should be appropriate to the communicative aim [16, p. 40]. The cooperative principle is developed into four maxims:

1) maxims of quantity: the information in the speech act shouldn't exceed the limit;

2) maxim of quality: tell the truth;

3) maxim of relation: be relevant;

4) maxim of manner: speak clearly, speak consistently.

On the other hand, G. N. Leech argues that cooperative principle cannot be applied in textual communication as it is based on the principles of clarity, language economy and expressiveness $[17$, p. 250]. Furthermore G. N. Leech proposes the principle of politeness which is based on maxims of tact, approval, modesty, nobility and irony. So, there are different principles of communication and in distinct situations some of them may dominate in accordance with sociocultural conditions.

Discourse theory lies on the basis of the pragmatic analysis. Although this notion has different definitions, many scientists support its situational interpretation. It means that discourse should be investigated in relation with social, psychological and cultural conditions of communication. The situational interpretation in its turn introduces the notion of communicative-pragmatic situation and its characterization by external conditions of communication. E. S. Aznaurova suggests to 
define communicative-pragmatic situation by a chain of questions: who - what - where - when - how - to whom [18, p. 38]. Communicative-pragmatic situation in the literary discourse can be analyzed by the following criteria:

-circumstances and places of the communicative act;

-the subject and aim of communication;

-social, ethnic, individual characteristics of the communicants;

-role and personal relations between communicants.

In pragmatic approach to the literary discourse two components of communication - impact and perception plays a great role as they form an integral process of communication. The analysis of the problems impact and perception relates to the notion of pragmatic intention. According to D. U. Ashurova six kinds of pragmatic intentions can be identified [1, p. 87]:

-the pragmatic intention 'to attract attention';

-the pragmatic intention 'to interest the reader';

-the pragmatic intention 'to exert an emotional impact';

-the pragmatic intention 'to activize knowledge structures' (relating to conceptual information);

-the pragmatic intention 'to stimulate the addressee's creativity';

-the pragmatic intention 'to represent the conceptual world picture'.

As the general pragmatic intention of literary discourse is to exert an aesthetic impact, different kinds of pragmatic intentions may be used in combination with each other.

In relation with the transition of linguistic paradigm to anthropocentric paradigm the functioning of the language is characterized by the cognitive activity of the human being. Consequently, in the analysis of the text both its communicative and cognitive peculiarities should be taken into account. At this point we rely on the statement formulated by E. Kubryakova that "any linguistic phenomenon can be described and explained adequately at the intersection of cognition and communication" [19, p. 11].

As is known, cognitive linguistics deals with the study of the mental processes of human experiences and as its results - knowledge. Language from cognitive perspective serves as a cognitive mechanism in the representation of linguistic and non-linguistic knowledge. Considering this, we can acknowledge that there is a strong relationship between cognitive linguistics and text linguistics, as the text that is the main means of transmitting information about the world. As it is stated by some linguists, each text reflects certain fragments of human experience and knowledge [20, p. 75]. Actually, the main aim of the conversation is to exchange an information, and, in this regard, information is understood as receiving new data about objects, phenomena, relations and events of objective reality. The term information is widely used in both cognitive linguistics and text linguistics. Many scholars approach the notion of information differently and they distinguish various types of information. I. R. Galperin differentiates three kinds of information: factual, subtextual and conceptual [21, p. 56]. These types of information mainly related to literary text and its interpretation. In this respect, the main purpose from the interpretation of text is to uncover conceptual information which depicts author's individual world picture.

Besides the types of information that are mentioned above, stylistic and pragmatic information is also differentiated [22, p. 78]. Stylistic information in its turn can be divided into emotional, evaluative and imagery information and it can be expressed implicitly or explicitly in the text. The main function of the stylistic information in the text is to exert an emotional and aesthetic impact on the reader. The stylistic information is very close notion to the pragmatic information since pragmatic information is also oriented on producing impact on the reader. 
However, pragmatic information does not only influence the reader emotionally but it calls the reader for some kind of action. Besides, pragmatic information includes the information about the linguistic personality, his social and professional status, role relations, individual-psychological characteristics and etc.

Another types of information can be found in the studies of T. A. van Djik who divided the information in the text into cognitive and contextual [23, p. 15]. From this point of view, cognitive information includes knowledge, beliefs, ideas and different viewpoints. Contextual information is reflected in speech acts, communicative situations and interactions. Another significant feature in the cognitive analysis of the text is the new (unknown) and old (given, known) types of information [24, p. 17]. The integration of the new information into the already given information and keeping a balance between these two types of information is the main criteria of the text foundation. It should be noted that the new information is perceived on the basis of already known information, which may be included in the preceding fragment of the text, belonging to the general knowledge of the addresser and addressee; it can enter into a person's thesaurus. The introduction of a new information and its integration with old information provides the adequate understanding and interpretation of the text. As a matter of fact, the process of introducing new information corresponds the principle of theme and rhyme relations in the text. To be more precise, old information is identified theme of the text and new information is the rheumatic material which introduced in the text.

An important role in the cognitive structure of the text has the distribution of information in the text. There are several cognitive principles of information distribution: the principle of iconicity, the correlation of old and new information, the principle of relevance and foregrounding, language economy / redundancy. The principle of iconicity is embedded in the relationship between the events of reality and their linguistic presentation. Thus, the sequence of sentences in the text as a whole should correspond the chronological order of events in reality. This concerns not only chronological, but spatial, causative, cause-and-effect relations, reflecting the development of events in reality. This does not mean, however, that the principle of iconicity is not violated in some types of text. For instance, the category of retrospection in fiction is characterized by the violation of the course of events and the reader is introduced with the events which happened earlier (flashback) or later (flash forward) than the present time.

Another cognitive principle of text construction is the principle of relevance. In line with this principle the most relevant and important information is highlighted in the verbal layer of the text. The choice of language forms and their organization in the text depends on what is considered essential by the addresser. The addresser specifies the most relevant information and composes text strategies to orientate the reader in text perception. Foregrounding attracts attention to certain parts of the text activating certain frames and makes the search of information easier. The notion of foregrounding is widely investigated in the works by scientists of Russian Formal School and Prague linguistic circle.

Language economy and linguistic redundancy being contradictory cognitive principles of distributing information in the text have paramount importance in conveying a mass of information in one linguistic unit or giving certain information by the recurrence of the same elements in the text (anaphora, epiphora, framing, coupling, gradation and etc.). In this respect, linguistic redundancy is not considered excessive use of linguistic units and functions as one of the cognitive principles of text construction.

The cognitive character of the text is maintained by the fact that any text is intended to be understood and interpreted, so it presupposes the cognitive activity aimed at revealing the semantic content of the text. So, in cognitive linguistics perception is concerned as a cognitive activity which 
relates to the processes of conceptualization and categorization. The notion of conceptualization has become a key notion in both cognitive linguistics and text linguistics. According to the text materials and background knowledge the addressee makes his own suppositions and conclusions. All this process is considered as one of the processes of human cognitive activity. Another human cognitive activity categorization assumed as a taxonomic activity maintained through the classification of various phenomena according to their significant, categorical characteristics [25, p. 245]. In accordance with the text, categorization allows the reader to generalize the separate facts which are taken from the text and combine them into certain conceptual systems. As a result, categorization relates to the formation of some concepts in the continuum of the text and set of concepts combined to the conceptospheres of the text.

Besides the cognitive approach to text analysis linguoculturology has also been important area in linguistic studies. It is acknowledged that effective communication is built on deep and wide background knowledge of speaker's culture which is reflected in the use of linguistic means including ways of life, mentality, vision of the world, the national character, customs, beliefs, values, kinds of social behavior [26, p. 13]. While analyzing the text from the position of linguoculturology we should take into account following postulates: a) language and culture is closely related; b) text is considered as the main means of studying culture, at the same time it is the main source of cultural knowledge and information.

The relationship between language and culture can be seen mostly in fictional texts. The main reason for this can be revealed in the fact that a fictional text by its nature is one of the forms of culture and a fictional text transmits sociocultural, aesthetic, emotional and evaluative information. Interpretation of this kind of texts requires linguocultural knowledge of national values and priorities.

To conclude all mentioned above we can make following assumptions:

-the study of the text from anthropocentric perspective reveals close relationships between text linguistics, communicative linguistics, cognitive linguistics and linguoculturology;

-communicative model of text interpretation assumes to consider the text as a main unit of communication having dual communicative character considered the factors of the addressee and addresser and wide sociocultural context;

-the study of the text from cognitive viewpoint shows complex cognitive structure of the communication which is built on the text construction and perception on the basis of the cognitive principles of distributing information in the text and the processes of its conceptualization and categorization;

-the analysis of the text from linguocultural aspect deals with the systems of linguocultural units which forms linguocultural platform of the text, the investigation of the cultural concepts as meaningful-thematic dominants of the text, considering the text as author's individual linguistic world picture.

\section{References:}

1. Ashurova, D. U. (2012). Text linguistics. Tashkent, Tafakkurqanoti.

2. Halliday, M. A. K. (1978). Language as social semiotic: The social interpretation of language and meaning. Hodder Arnold.

3. Brown, G. \& Yule, G. (1983). Discourse analysis. Cambridge University Press.

4. Crystal, D. (2008). A dictionary of Linguistics and Phonetics. 6th ed. Wiley Blackwell.

5. Harris, Z. (1952). Discourse analysis. Language, 28(1).

6. Widdowson, H. G. (1978). Teaching language as communication. Oxford University Press. 
7. Stubbs, M. (1983). Discourse analysis: The sociolinguistic analysis of natural language. V. 4. University of Chicago Press.

8. Karasik, V. I. (2004). Yazykovoi krug: lichnost', kontsepty, diskurs. Volgograd.

9. Arutyunova, N. D. (1990). Pragmatika. Lingvisticheskii entsiklopedicheskii slovar'. Moscow.

10. Bakhtin, M. M. (1979). Estetika slovesnogo tvorchestva. Moscow, Iskusstvo.

11. Kolshanskii, G. V. (1978). Tekst kak edinitsa kommunikatsii. Problemy obshchego i germanskogo yazykoznaniya. Moscow.

12. Kubryakova, E. S. (1994). Tekst i ego ponimanie. Russkii tekst, (2).

13. Bolotnova, N. S. (1998). About the status of textual communicative stylistics and its perspectives. Izvestiya Altaiskogo gosudarstvennogo universiteta, (3), 91-95.

14. Dridze, T. M. (1980). Yazyk i sotsial'naya psikhologiya. Moscow, Vysshaya shkola.

15. Austin, J. L. (1962). How to Do Things with Words. Oxford, Oxford University Press, 167.

16. Grice, H. P. (1975). Logic and conversation. In: Cole, P., and Morgan, J. (eds.). Syntax \& Semantics, 3 .

17. Leech, G. N. (2016). Principles of pragmatics. Routledge.

18. Aznaurova, E. S. (1988). Pragmatika khudozhestvennogo slova. Tashkent, Fan, 38.

19. Kubryakova, E. S. (2006). Obrazy mira v soznanie cheloveka i slovoobrazovatel'nye kategorii kak ikh sostavlyayushchie. Izvestiya RAN. Seriya literatury i yazyka, 65(2), 3-13.

20. Kubryakova, E. S. (2001). O tekste i kriteriyakh ego opredeleniya. In: Struktura $i$ semantika, v. 1, Moscow, 72-81.

21. Galperin, I. R. (1981). Tekst kak ob"ekt lingvisticheskogo napravleniya. Moscow, Nauka.

22. Naer, V. L. (2001). Iz lektsii po teoreticheskim osnovam interpretatsii teksta. Moscow.

23. Van, D. T., \& Teun, A. (1977). Text and context: explorations in the semantics and pragmatics of discourse. London and New York, Longman.

24. Prince, E. F. (1981). Towards a taxonomy of given-new information. Radical pragmatics.

25. Kubryakova, E. S., Dem'yankov, V. Z., Pankrats, Yu. G., \& Luzina, L. G. (1996). Kratkii slovar' kognitivnykh terminov. Moscow, Filol. fak. MGU, 245.

26. Ter-Minasova, S. G. (2000). Yazyk i mezhkul'turnaya kommunikatsiya. Moscow. Slovo/Slovo, 261.

\section{Список литературь:}

1. Ashurova D. U. Text linguistics. Tashkent: Tafakkurqanoti, 2012.

2. Halliday M. A. K. Language as social semiotic: The social interpretation of language and meaning. Hodder Arnold, 1978.

3. Brown G., Yule G. Discourse analysis. Cambridge University Press, 1983.

4. Crystal D. A dictionary of Linguistics and Phonetics. 6th ed. Wiley Blackwell, 2008.

5. Harris Z. Discourse analysis. Language, 1952. V. 28. №1.

6. Widdowson H. G. Teaching language as communication. Oxford University Press, 1978

7. Stubbs M. Discourse analysis: The sociolinguistic analysis of natural language. University of Chicago Press, 1983. V. 4.

8. Карасик В. И. Языковой круг: личность, концепты, дискурс. Волгоград, 2004.

9. Арутюнова Н. Д. Прагматика // Лингвистический энциклопедический словарь. М., 1990.

10. Бахтин М. М. Эстетика словесного творчества. М: Искусство, 1979. 
11. Колшанский Г. В. Текст как единица коммуникации // Проблемы общего и германского языкознания. М., 1978.

12. Кубрякова Е. С. Текст и его понимание // Русский текст. 1994. №2.

13. Болотнова Н. С. О статусе коммуникативной стилистики текста и перспективах ее развитие // Известия Алтайского государственного университета. 1998. №3 (7). С. 91-95.

14. Дридзе Т. М. Язык и социальная психология. М: Высшая школа, 1980.

15. Austin J. L. How to Do Things with Words. Oxford: Oxford University Press, 1962. $167 \mathrm{p}$.

16. Grice H. P. Logic and conversation // Syntax \& Semantics / ed. by P. Cole, J. Morgan. 1975. V. 3. P. 41-58.

17. Leech G. N. Principles of pragmatics. Routledge, 2016.

18. Азнаурова Э. С. Прагматика художественного слова. Ташкент: Фан, 1988. 38 с.

19. Кубрякова Е. С. Образы мира в сознание человека и словообразовательные категории как их составляющие // Известия РАН. Серия литературы и языка. 2006. Т. 65. №2. C. 3-13.

20. Кубрякова Е. С. О тексте и критериях его определения // Структура и семантика 2001. T. 1. M. C. 72-81.

21. Гальперин И. Р. Текст как объект лингвистического направления. М.: Наука, 1981.

22. Наер В. Л. Из лекций по теоретическим основам интерпретации текста. М., 2001.

23. Van D. T. A., Teun A. Text and context: explorations in the semantics and pragmatics of discourse. London and New York: Longman, 1977.

24. Prince E. F. Towards a taxonomy of given-new information. Radical pragmatics, 1981.

25. Кубрякова Е. С., Демьянков В. 3., Панкрац Ю. Г., Лузина Л. Г. Краткий словарь когнитивных терминов. М.: Филол. фак. МГУ, 1996. 245 с.

26. Тер-Минасова С. Г. Язык и межкультурная коммуникация. М.: Слово/Slovo, 2000. $261 \mathrm{c}$.

Работа поступила

в редакичию 22.06.2019 2.
Принята к публикачии 27.06.2019 2.

Ссылка для циитирования:

Usmonova D. Anthropocentric Model of Discourse // Бюллетень науки и практики. 2019. T. 5. №8. C. 209-217. https://doi.org/10.33619/2414-2948/45/23

Cite as (APA):

Usmonova, D. (2019). Anthropocentric Model of Discourse. Bulletin of Science and Practice, 5(8), 209-217. https://doi.org/10.33619/2414-2948/45/23 